\title{
The History of Science
}




\section{Making the History of Early Modern Science Reflections on a Discipline in the Age of Globalization*}

The French public's recent "discovery" of certain British and American classics of the history of science is a cue for reflection on the current place of this field in the social sciences more broadly. While the question has reemerged regularly over the last fifty years, in France the topic has been primarily-though not exclusively-approached from the perspective of its place within the major debates led by successive generations of the Annales. It has also been a particular point of exchange with the anglophone world, where a few research centers (notably in the UK) have distinguished themselves by the originality of their approaches. To grasp the variety of these exchanges, with an eye to their strengths, blind spots, and above all the diversity of their referents, would require a precise map charting their different points of orientation-a map we do not yet have at our disposal. And so, starting from the current state of affairs (and adopting a rather French perspective), I will attempt to retrace and unravel some of the many threads that can be pulled from these exchanges. Sketching out a return to the historiographical horizon of the 1980s will perhaps make it possible to better characterize, even broadly, the study of science and technology, the methodological issues that it raises, and the

This article was translated from the French by Angela Krieger and edited by Chloe Morgan and Stephen Sawyer.

* I would like to thank the review board of the Annales, who carefully read and critiqued the initial version of this article. I would also like to thank the following colleagues who willingly shared their doubts, comments, and thoughts with both honesty and generosity: Wolf Feuerhahn, Sabina Loriga, Rafael Mandressi, Dominique Pestre, Silvia Sebastiani, Stéphane Van Damme, and especially Simon Schaffer. 
multiplicity of its relationship to the social sciences within both French and international research. In doing so, I hope to enrich our readings of Simon Schaffer, historian of science at the University of Cambridge. The second part of this article will focus on a discussion of his text published in this issue of the Annales.

A wave of works from different historiographical traditions have recently been translated into French, all of which share a strong linguistic and institutional grounding in the anglophone world. In chronological order of their publication, they include: a collection of Schaffer's articles published over the last thirty years, primarily in the 1990 s $^{1}$; a book by Steven Shapin, historian of science at Harvard, first published in 1994²; and a text by Lorraine Daston, a historian of science based in Chicago and Berlin, chosen from among her abundant corpus and first published in $1995 .{ }^{3}$ These works refer back to different epistemological approaches that have (or have not) been systematized and which dialogue with each other either directly or indirectly. It is useful to emphasize that, at a time when the scope of the longue durée addressed in the social sciences in France seems to be shrinking, these authors are all specialists of the early modern and modern periods-or have at least developed their research based on extended periods of time that often straddle the traditional French dividing line set at the Revolution. ${ }^{4}$ Each of these

1. Simon Schaffer, La fabrique des sciences modernes, XVII ${ }^{e}$-XIX $X^{e}$ siècle, trans. Frédérique AïtTouati, Loïc Marcou, and Stéphane Van Damme (Paris: Éd. du Seuil, 2014). This work constitutes one of the author's first "books," published three years after a collection of articles translated into Spanish: Schaffer, Trabajos de cristal: Ensayos de historia de la ciencia, 1650-1900, trans. Miguel Martiénez-Lage and Juan Pimentel (Madrid: Marcial Pons, 2011). The Spanish volume proposes a different selection of texts that throws the technological dimension of the investigation Schaffer has been conducting over the years into clearer relief. All of the articles chosen for the French volume, with the exception of "Newton on the Beach," were written between the mid-1980s and the mid1990s. It should also be highlighted that the volume's title was chosen by the editor and not the author.

2. Steven Shapin, Une histoire sociale de la vérité. Science et mondanité dans l'Angleterre du XVII ${ }^{e}$ siècle, trans. Samuel Coavoux and Alcime Steiger (Paris: La Découverte, 2014). Originally published as A Social History of Truth: Civility and Science in Seventeenth-Century England (Chicago: University of Chicago Press, 1994).

3. Lorraine Daston, L'économie morale des sciences modernes. Jugements, émotions et valeurs, trans. Samuel Lézé (Paris: La Découverte, 2014). Originally published as "The Moral Economy of Science," Osiris 10 (1995): 3-24. In the French volume, the translated article is accompanied by two texts by Stéphane Van Damme: "Lorraine Daston et la nouvelle histoire intellectuelle des sciences," 7-18, and "Nous n'avons jamais été désintéressés : les sciences entre moralisation, éthique et affects," 65-108. Himself an important figure in the international community of historians of science, Van Damme is the author of numerous studies that have greatly contributed to renewing the field for the early modern period. I will limit myself to citing his most recent book, À toutes voiles vers la vérité. Une autre histoire de la philosophie au temps des Lumières (Paris: Éd. du Seuil, 2014). He also contributed to the French translation of Schaffer's collected articles mentioned in note 1 .

4. Within Shapin's extensive bibliography, I will simply cite his important contribution to the modern history of scientists: The Scientific Life: A Moral History of a Late Modern Vocation (Chicago: Chicago University Press, 2008). 
scholars therefore carves out distinct areas within "modernity" with their own specific anchoring points, but they all develop their studies in light of moments dating further back in time-which makes comparing their approaches particularly interesting. It shows just how much they have contributed to challenging the paradigm upon which the grand narrative of the discipline is based: that of the "scientific revolution" conceived as the founding moment of European societies' commitment to modernity. ${ }^{5}$ These texts, originally written at the turn of the $1990 \mathrm{~s}$, should be read with two perspectives and two temporalities in mind. On the one hand, we should consider the differences between the worlds that produced these texts and those that read them; on the other, the intellectual climate of the 1990s should be compared with that of today.

\section{A Critique of the "Scientific Revolution" and a Critique of Science}

\section{The Conditions of a New Debate}

Nineteen ninety-three was marked by two publications produced simultaneously in two different places. The book that was to become the new reference on Galileo, Galileo, Courtier by Mario Biagioli, was published by a prestigious university press in the United States, ${ }^{6}$ just as the French translation of Steven Shapin and Simon Schaffer's Leviathan and the Air-Pump, a study of Thomas Hobbes and Robert Boyle's mid-seventeenth-century quarrel about the vacuum, was being released. ${ }^{7}$ The appearance of these two works on the French scene was a sign that anglophone historiography (composed of many different traditions) had entered a world that

\footnotetext{
5. This paradigm was resolutely surpassed in Schaffer's study of the quarrel between Robert Boyle and Thomas Hobbes cited in note 7. For Daston, see the texts by Van Damme cited in note 3 and Didier Fassin, "Les économies morales revisitées," Annales HSS 64, no. 6 (2009): 1237-66.

6. Mario Biagioli, Galileo, Courtier: The Practice of Science in the Culture of Absolutism (Chicago: University of Chicago Press, 1993). Whether or not Biagioli's book circulated in France remains unknown, but awareness of his work was undoubtedly facilitated by the publication, two years later, of the article "Le prince et les savants. La civilité scientifique au XVII ${ }^{\mathrm{e}}$ siècle," Annales HSS 50, no. 6 (1995): 1417-53. By placing the sociological perspective developed in Norbert Elias' studies of Old Regime courtly societies at the center of his analysis, Biagioli proposed a shift in the sociological study of science along very different lines from science studies: the court (and therefore the prince) became one of the primary centers of scholarly innovation. In this way, he also broke new ground in Galilean studies by going beyond Pietro Redondi's analysis, which aimed to reread the ins and outs of Galileo's trial in terms of atomist philosophy: Pietro Redondi, Galileo Heretic, trans. Raymond Rosenthal (Princeton: Princeton University Press, 1987).

7. Steven Shapin and Simon Schaffer, Léviathan et la pompe à air. Hobbes et Boyle entre science et politique, trans. Thierry Piélat (Paris: La Découverte, 1993). Originally published as Leviathan and the Air-Pump: Hobbes, Boyle and the Experimental Life (Princeton: Princeton University Press, 1985).
} 
was still focused on a French vision of the discipline and its French references. ${ }^{8}$ It was also a sign that the grand narrative of modern science, primarily represented in the mid-twentieth century by the work of Alexandre Koyré, could potentially be revised. Though he contributed to bringing together history and the history of science-traditionally dominated by philosophers and largely oriented toward the physical and mathematical sciences-Koyré nonetheless remained a man of "the history of scientific thought," 9 as reflected in the title of the chair created for him, with the active support of Fernand Braudel, in the newly established Sixth Section of the École pratique des hautes études, specializing in economic and social sciences. The Centre de recherche en histoire des sciences et des techniques, which was added to it in 1958, was renamed after Koyré two years after his death in 1964 and pursued the research program he had forged.

Twenty years later, from the mid-1980s, studies emerging from across the Channel or the Atlantic, but also from related disciplines, encouraged a shift from thought to practice, from texts to individuals and the political, social, and economic dynamics that enveloped the question of "making science." The study of scholarly controversies, inherited from science studies, diversified the types of objects considered, while the exploration of patronage and sociabilities brought in new kinds of actors. Each following their own distinct trajectory, and despite the original English version of one being written almost ten years before the other, the books by Biagioli and Shapin and Schaffer called for new investigations into the historicization of the production of science. They confirmed the possibility of considering

8. As early as 1982, Michel Callon and Bruno Latour edited a collection of Englishlanguage articles translated into French and entitled La science telle qu'elle se fait. Anthologie de la sociologie des sciences de langue anglaise (Paris: Pandore, 1982). It was reprinted in 1991 by Éditions La Découverte, and its immediate reception calls out to be studied. The volume made two of Shapin's articles available in French: "Pump and Circumstance: Robert Boyle's Literary Technology," Social Studies of Science 14 (1984): 481-520, appeared as "Une pompe de circonstance: la technologie littéraire de Boyle"; "Phrenological Knowledge and the Social Structure of Early Nineteenth-Century Edinburgh," Annals of Science 32, no. 3 (1975): 219-43, as "La politique des cerveaux: la querelle phrénologique au XIX ${ }^{\mathrm{e}}$ siècle à Édimbourg."

9. Alexandre Koyré, From the Closed World to the Infinite Universe (Baltimore: Johns Hopkins Press, 1957), vii: "Time and again, when studying the history of scientific and philosophical thought in the sixteenth and seventeenth centuries-they are, indeed, so closely interrelated and linked together that, separated, they become ununderstandable-I have been forced to recognize, as many others have before me, that during this period human, or at least European, minds underwent a deep revolution which changed the very framework and patterns of our thinking and of which modern science and modern philosophy are, at the same time, the root and the fruit. This revolution or, as it has been called, this 'crisis of European consciousness,' has been described and explained in many different ways." Koyré's two major works centered on the history of philosophical thought and on the history of scientific thought: Études d'histoire de la pensée philosophique (Paris: Armand Colin, 1961), and Études d'histoire de la pensée scientifique (Paris: Puf, 1966). On Koyré, see: Pietro Redondi, ed., "Science: The Renaissance of a History," special issue, History and Technology: An International Journal 4, no. 1/4 (1987); Redondi (Paris: Éd. de l'EHEss, 1986). 
the post-Koyré turn in France at a moment when other indicators announced that the time had come to put science into context. ${ }^{10}$

The different fates of these two books (the first of which has yet to be translated into French) provide a good indication of the various inflections and phases of the debate that began in the 1990s within the framework of increasingly internationalized and interdisciplinary research. ${ }^{11}$ In France, this broadly included philosophers, historians, anthropologists, economists, and sociologists, some of whom-though not all-were specialists in science, as echoed in the title of a collective work published in 1998: Des sciences et des techniques, un débat (Sciences and technologies: a debate). ${ }^{12}$ Launched at the École des hautes études en sciences sociales, the debate aimed to highlight proposals to renew the field, as a certain number of articles published in the Annales during this period had already indicated. In 1995, Dominique Pestre signed a sort of manifesto "for a social and cultural history of science." 13 From the very title of his essay, Pestre presented himself as the spokesman for a new, distinctly French history of science, capable of taking up the mantle as it had been reconfigured by the Annales over the two preceding decades. ${ }^{14}$ Through his references, he envisioned this renewal in connection with a group of authors from the anglophone world who had contributed to the creation of what is now called "science studies." He also drew on a dialogue with the Centre de sociologie de l'innovation, founded at the École des mines in

10. The journal Science in Context was thus founded in 1987 with the following mission statement: "Science in Context is an international journal ... devoted to the study of the sciences from the points of view of comparative epistemology and historical sociology of scientific knowledge. The journal is committed to an interdisciplinary approach to the study of science and its cultural development-it does not segregate considerations drawn from history, philosophy and sociology. Controversies within scientific knowledge and debates about methodology are presented in their contexts."

11. It is worth noting that French reviews of the original English edition of Leviathan were often along critical lines: Dominique Pestre, review of Shapin and Schaffer, Leviathan and the Air-Pump, in Revue d'histoire des sciences 43, no. 1 (1990): 109-16.

12. Roger Guesnerie and François Hartog, eds., Des sciences et des techniques. Un débat (Paris: Éd. de l'Ehess, 1998).

13. Dominique Pestre, "Pour une histoire sociale et culturelle des sciences. Nouvelles définitions, nouveaux objets, nouvelles pratiques," Annales HSS 50, no. 3 (1995): 487522. That same year, the journal published a dossier entitled "Rhétorique et civilité. L'histoire des sciences, XVI ${ }^{\mathrm{e}}-\mathrm{XVII}{ }^{\mathrm{e}}$ s.," Annales HSS 50, no. 6 (1995), made up of Giovanna Ciffoletti, "La question de l'algèbre. Mathématiques et rhétorique des hommes de droit dans la France du XVI e siècle," 1385-416, and Mario Biagioli, "Le prince et les savants." Two years later, in 1997, Annales HSS 52, no. 5 contained a dossier devoted to "Les expéditions scientifiques" and including the following studies: Marie-Noëlle Bourguet and Christian Licoppe, "Voyages, mesures et instruments. Une nouvelle expérience du monde au Siècle des lumières," 1115-51; Kapil Raj, "La construction de l'empire de la géographie. L'odyssée des arpenteurs de Sa Très Gracieuse Majesté, la reine Victoria, en Asie centrale," 1153-80.

14. Here, I would like to refer to Jacques Le Goff and Pierre Nora, eds., Faire de l'histoire (Paris: Gallimard, 1974), vol. 1, Nouveaux problèmes, vol. 2, Nouvelles approches, and vol. 3, Nouveaux objets. The title of Pestre's article "Pour une histoire sociale" borrows this threefold division. 
1967, where research led by Michel Callon and Bruno Latour elaborated a "sociology of translation" based on actor-network theory and investigations into the anthropology of science and technology, research and innovation policies, and the construction of markets and practices. ${ }^{15}$ It is significant that Pestre chose to publish his manifesto in the Annales and not the Revue d'histoire des sciences or the Revue de synthèse, both well-established outlets for other epistemological traditions in France (the histories of which still need to be written). ${ }^{16}$ In fact, the proposal to renew the discipline and its actors had already been broached a few years earlier, within the new institutional framework of the Centre de recherche en histoire des sciences et des techniques, backed by the recently created Cité des sciences et de l'industrie. Though rather interesting, its results have remained relatively unknown, despite a publication which set out to appraise the impact of research produced in the 1970 s and 1980 s on the historical and sociological study of science. ${ }^{17}$ This book was mainly about the role the sociology of science-as opposed to both philosophy and history-should play in reflections on science and modern technologies.

Des sciences et des techniques, un débat mobilized a broader community of specialists in the social sciences, thus revealing the dividing lines that were emerging between various currents grouped under different disciplinary banners in philosophy, history, anthropology, or sociology. The sociology of science was represented by Latour ${ }^{18}$ who, regularly dialoguing with anglophone scholars in Britain and the United States (and thus playing an important role in the translation projects mentioned above), represented a new research perspective on the French scene.

15. Michel Callon, "Éléments pour une sociologie de la traduction. La domestication des coquilles Saint-Jacques et des marins-pêcheurs dans la baie de Saint-Brieuc," special issue "La sociologie des Sciences et des Techniques," L'année sociologique, 3rd ser., 36 (1986): 169-208. That same year, the English translation was published in John Law, ed., Power, Action and Belief: A New Sociology of Knowledge? (London: Routledge and Kegan Paul, 1986). For a summary, see Madeleine Akrich, Michel Callon, and Bruno Latour, Sociologie de la traduction. Textes fondateurs (Paris: Presses des Mines, 2006). See also Bruno Latour, We Have Never Been Modern, trans. Catherine Porter (Cambridge: Harvard University Press, 1993).

16. On the Centre international de synthèse, see Agnès Biard, Dominique Bourel, and Éric Brian, eds., Henri Berr et la culture du XX siècle. Histoire, science et philosophie (Paris: Albin Michel, 1996); Enrico Castelli Gattinara, Les inquiétudes de la raison. Épistémologie et histoire en France dans l'entre-deux-guerres (Paris: Vrin/Éd. de l'EHEss, 1998).

17. Dominique Pestre, introduction to L'étude sociale des sciences. Bilan des années 1970 et 1980 et conséquences pour le travail historique, ed. Dominique Pestre (Paris: Cité des sciences et de l'industrie, 1992), 5-13.

18. Bruno Latour, "Les chantiers actuels des études sociologiques sur les sciences exactes," in Guesnerie and Hartog, Des sciences et des techniques, 11-24. The modest title of this article is quickly belied by the definition of science studies proposed on its first page: "[a] hitherto marginal domain that intersects and reformats preoccupations coming from history, philosophy, sociology, anthropology, economics, and psychology applied to scientific practices and technologies as they are developed in laboratories and research departments." For a more recent account that summarizes and develops earlier observations, see Dominique Pestre, Introduction aux science studies (Paris: La Découverte, 2006). 
He was not alone. The contribution of Jean-Claude Perrot advanced another proposition to renew the field that relied on history, though it was not presented as programmatic. A third proposal more discreetly looked to epistemology and the philosophy of science, notably through the texts on scientific objectivity compiled by Daston. Technology also assumed its rightful place as a leading object of study and a social issue, and was covered in three sections devoted to innovation, material culture, and economics. ${ }^{19}$ Significantly, Koyré's project no longer had a place in all this, despite its promise, formulated after the Second World War, of a "history of philosophical and scientific ideas" reinvigorated by a dialogue with history. ${ }^{20}$

\section{The History of Science and History}

In fact, sometime around the 1990s, the debate on the "scientific revolution"—notably as it had been revived in Britain - had already moved on considerably from both Koyre's propositions and the ideas inherited from a positivist conception of the history of science that had persisted well into the 1970s. ${ }^{21}$ However in France, precisely because it had been undertaken elsewhere, criticism of the paradigm did not influence the entire profession (already rife with internal divisions). Studies on Galilean and classical science continued to develop, centered on major figures within their respective national pantheons-Galileo, René Descartes, and Isaac Newton. ${ }^{22}$ These publications were based on a considerable labor of critical reading

19. See the table of contents, which brings together some thirty articles based on seven themes: the sociology of science is paired with intellectual history; epistemology is placed alongside social history; area studies are examined through the lens of the relationship between scholarly traditions and cognition; and an entire section is devoted to the issue of scientific objectivity, based on Daston's proposal.

20. See above, n. 9.

21. The golden age of great syntheses experienced an initial moment of glory in the 1950s: Alfred Rupert Hall, The Scientific Revolution, 1500-1800: The Formation of the Modern Scientific Attitude (London: Longmans, Green and Co., 1954); Koyré, From the Closed World; Thomas S. Kuhn, The Copernican Revolution: Planetary Astronomy in the Development of Western Thought (Cambridge: Harvard University Press, 1957); and Herbert Butterfield, The Origins of Modern Science, 1300-1800, revised ed. (New York: Macmillan, 1957). It was relayed in France by, for example, René Taton, ed., Histoire générale des sciences, 3 vols. (Paris: PuF, 1957-1964). For works that began putting things into perspective in the 1990s, see: David C. Lindberg and Robert S. Westman, eds., Reappraisals of the Scientific Revolution (Cambridge: Cambridge University Press, 1990); Steven Shapin, The Scientific Revolution (Chicago: University of Chicago Press, 1996); Margaret J. Osler, ed., Rethinking the Scientific Revolution (Cambridge: Cambridge University Press, 2000); and Peter Dear, Revolutionizing the Sciences: European Knowledge and its Ambitions, 15001700 (Princeton: Princeton University Press, 2001). For a presentation of this historiography, see H. Floris Cohen, The Scientific Revolution: A Historiographical Inquiry (Chicago: University of Chicago Press, 1994).

22. On the case of Descartes, see: François Azouvi, Descartes et la France. Histoire d'une passion nationale (Paris: Fayard, 2002); Stéphane Van Damme, Descartes. Essai d'histoire culturelle d'une grandeur philosophique (Paris: Presses de Sciences Po, 2002). The same type of study could be carried out for all "national heroes," and the historiography devoted to them read as a process of "nationalization," in the tradition of a type of 
and source-editing, representative of the alliance between philology and philosophy. They left it to historians to venture down secondary paths exploring minor figures and social categories (which were not on the agendas of historians of science at the time) as well as the issues of scholarly networks and scientific publication. They avoided-mainly out of ignorance-the increasing number of studies that, following Joseph Needham, pushed examination of the scientific revolution outside the ordinary territories of modernity, namely Europe. ${ }^{23}$ Of course, the genre of overarching grand narratives would ultimately come to be considered a thing of the past. However, the large number of elements that were already being reworked and which would contribute to the recomposition of a domain that had never really been unified had not yet become fully visible. Only a few signs had been registered, such as the "rise, among general historians, of research pertaining in one way or another to the history of science and technology." 24

The quiet arrival of "general historians" can be interpreted as one of the major results to emerge from the "critical turn" of the Annales, itself grounded in ongoing projects related to the social history of culture in the 1970s and 1980s. Different types of undertaking can be distinguished within this movement: investigations of Enlightenment sociability, the Republic of Letters and Science, and correspondence and scholarly networks, centered around the work of Daniel Roche ${ }^{25}$; studies of the revolution in printed text, books, and their readers,

history of science established as a genre from the Enlightenment. On Galileo, see Ludovico Geymonat, Galileo Galilei: A Biography and Inquiry into His Philosophy of Science, trans. Stillman Drake (New York: McGraw-Hill, 1965).

23. The "Science and Empires" program is run by the commission of the same name, which is part of the "History of Science" division of the International Union of History and Philosophy of Science and Technology. Among the publications in this domain, see: Roy MacLeod and Philip F. Rehbock, eds., Nature in its Greatest Extent: Western Science in the Pacific (Honolulu: University of Hawaii Press, 1988); Catherine Jami, Patrick Petitjean, and Anne-Marie Moulin, eds., Science and Empires: Historical Studies about Scientific Development and European Expansion (Dordrecht: Kluwer, 1992). As important as it was and despite what it said about the capacity of French research to contribute to the field-it is worth referring to Roshdi Rashed, ed., Histoire des sciences arabes (Paris: Éd. du Seuil, 1997), 3 vols.- this type of approach did not become part of the general landscape of the history of science until the end of the 1990s, notably within the framework of seminars held by the Centre Alexandre Koyré.

24. Éric Brian, "Action et abstraction. Notes d'actualité sur l'histoire des sciences," in Guesnerie and Hartog, Des sciences et des techniques, 41. See also Brian, "Ce que l'histoire des sciences peut apprendre de l'histoire. Le cas de l'Académie royale des Sciences à l'époque moderne," in La science à l'époque moderne (Paris: Presses de l'université de Paris-Sorbonne, 1998), 59-70, published under the aegis of the Association of Early Modernist Historians in French Universities.

25. Daniel Roche, Le siècle des Lumières en province. Académies et académiciens provinciaux, 1680-1789 (Paris/La Haye: EhEss/Mouton, 1978); Roche, Les Républicains des lettres. Gens de culture et Lumières au XVIII ${ }^{e}$ siècle (Paris: Fayard, 1988). On the legacy of Roche and the many ways in which his work nourished the history of science and technology, see 
pioneered by Henri-Jean Martin and Roger Chartier ${ }^{26}$; new research on the history of geography and the nature of space, in the vein of Bernard Lepetit and Daniel Nordman ${ }^{27}$; publications on the science of governance and managing territories, exemplified in the work of Jean-Claude Perrot ${ }^{28}$; and similar works on the science of man and naturalism, led by Jacques Roger. ${ }^{29}$ In the works that stemmed from these studies, there was a shift toward criticism of the paradigm of the industrial revolution, with the youngest generation also participating in the debate on the connections between the scientific revolution, the industrial revolution, and the growth of capitalism opened by Margaret Jacob. ${ }^{30}$ Numerous bridges were built between these various lines of inquiry, all contributing to the renewal of the dialogue between science and technology that had been interrupted by the grand narrative of the scientific revolution. In other words, while France had not experienced a federating controversy emblematic of a new way of envisioning science during the early modern period, French researchers had embraced a manifold form of modernity.

In the mid-1990s, a "new history of science" thus drafted a modified map of future projects, examining the non-institutional places of science (from typographers' workshops to salons and courts, from coffee houses to arsenals), scholarly practices as well as concepts, and circulation as something beyond the simple process of transmission. By sketching out different road maps, these new approaches hastened the crisis of the paradigm of the scientific revolution understood as an epistemological rift generated by exceptional individuals and centered on objects of a strictly intellectual nature. In the $1990 \mathrm{~s}$, in other words, the presence of historians

26. Elizabeth L. Eisenstein, The Printing Revolution in Early Modern Europe (Cambridge: Cambridge University Press, 1983). In the French tradition inaugurated by Lucien Febvre, see Henri-Jean Martin and Roger Chartier, eds., Histoire de l'édition française (Paris: Promodis, 1982-1986), 4 vols.

27. Bernard Lepetit, Carnet de croquis. Sur la connaissance historique (Paris: Albin Michel, 1999). Daniel Nordman was influential in the flourishing of imperial and colonial themes in the wake of research centered on the Mediterranean: Marie-Noëlle Bourguet, Bernard Lepetit, Daniel Nordman, and Maroula Sinarellis, eds., L'invention scientifique de la Méditerranée. Égypte, Morée, Algérie (Paris: Éd. de l'EHEss, 1998).

28. Jean-Claude Perrot, Une histoire intellectuelle de l'économie politique, XVII ${ }^{e}$-XVIII ${ }^{e}$ siècles (Paris: Éd. de l'EHEss, 1992); Marie-Noëlle Bourguet, Déchiffrer la France. La statistique départementale à l'époque napoléonienne (Paris: Éd. des Archives contemporaines, 1988); and Éric Brian, La mesure de l'État. Administrateurs et géomètres au XVIII siècle (Paris: Albin Michel, 1994).

29. Jacques Roger, Buffon: A Life in Natural History, trans. Sarah Lucille Bonnefoi (Ithaca: Cornell University Press, 1997); Roger, Pour une histoire des sciences à part entière, ed. Glaude Blanckaert (Paris: Albin Michel, 1995); Blanckaert, ed., Le terrain des sciences humaines. Instructions et enquêtes (XVIII ${ }^{e}-X^{e}$ siècle) (Paris: L'Harmattan, 1996); and Pietro Corsi, The Age of Lamarck: Evolutionary Theories in France, 1770-1830, trans. Jonathan Mandelbaum (Berkeley: University of California Press, 1988).

30. Margaret Jacob, The Cultural Meaning of the Scientific Revolution (New York: Knopf, 1988); Philippe Minard, La fortune du colbertisme. État et industrie dans la France des Lumières (Paris: Fayard, 1998); and Liliane Hilaire-Pérez, L'invention technique au siècle des Lumières (Paris: Albin Michel, 2000). 
in the epistemological and theoretical debates feeding the social sciences encouraged the identification of different epistemological registers that could be used to evaluate the legitimacy of both scholarly pronouncements and the collectives that contributed to producing them.

At this time, reception of Shapin and Schaffer's works in France depended as much on their potential proximity to the questions historians were already asking as on the growing importance of science studies, which still had a relatively low profile. This is clear in Chartier's review of the translation of Shapin and Schaffer's book on the air-pump, published in Le Monde des livres. ${ }^{31}$ The historian of books and the written word was particularly interested in the "new and decisive subjects offered by the history of science: the specific logics governing experimental practices, modes of certification and technologies of proof, textual and material ways of transmitting knowledge, and the forms established between the conception of scientific practice and the method of exerting power." ${ }^{32}$ All of these subjects are recognizable and relevant for the historian. ${ }^{33}$

\section{Science(s) and the Social Sciences}

However, to trace the turn that took place in the history of science in France during the 1990s, it is not enough to follow the single guiding thread of the scientific revolution. The methodological and epistemological debates I have broadly sketched out were not limited to the early modern period. They also introduced an analytical tool, "regimes of knowledge," which encouraged historians to distinguish less between periods that succeeded one another based on a rhythm of rupture and/or paradigm shifts than between the discontinuities that marked distinct sociopolitical and economic configurations. Just as we may speak of an "old regime" of knowledge production, the growing number of studies focused on more recent periods has notably brought to light the existence of a modern "regime" of technoscience. ${ }^{34}$

31. Roger Chartier, review of Shapin and Schaffer, Leviathan and the Air-Pump, in Le Monde des livres, January 28, 1994, p. viii. Other contemporary reviews published in French include the following: Pietro Redondi in Annales HSS 51, no. 2 (1996): 362-64; Gilles Chabaud in Revue d'histoire moderne et contemporaine 43, no. 2 (1996): 382-84; and Loï Blondiaux in Politix 8, no. 32 (1995): 176-81. For a critique of the historical training of historians of science in the 1980s and 1990s, see Lorraine Daston, "Science Studies and the History of Science," in "The Fate of Disciplines," ed. James Chandler and Arnold I. Davidson, special issue, Critical Inquiry 35, no. 4 (2009): 798-816.

32. Chartier, review, viii.

33. With this in mind, it is even more astonishing that Shapin's Social History of Truth, which was originally written and published in English less than a dozen years after Leviathan and the Air-Pump and which constitutes an extension of this book both methodologically and thematically, has only recently been published in a French translation (see above, note 2). And yet it was an important, audacious, and innovative work capable of speaking to a wide group of specialists from different intellectual traditions. See the review by Jean-Yves Grenier, "Les habits de la vérité. La validation scientifique vue comme une production sociale, selon Steven Shapin," Libération, June 5, 2014, pp. vi-vii. 34. On this notion, see the critique of Michael Gibbons et al., eds., The New Production of Knowledge: The Dynamics of Science and Research in Contemporary Societies (London: Sage 
What remains today of this moment of critical refoundation? What perspectives does this new road map of research open up? While this article does not offer an exhaustive and unequivocal response to these two questions, it nonetheless seeks to indicate some of the major shifts that have taken place since this moment. These shifts have contributed to expanding the world of the "history of science and technology" and have brought to light new cross-disciplinary questions that extend beyond the perimeter of the social sciences to the natural, earth, and life sciences. In particular, they have caused the question of nature to emerge in a new form. ${ }^{35}$ In the debates of the 1990 s, this issue figured primarily through the work of anthropologists and was examined according to multiple lines of inquiry, in turn adapted to fit distinct research programs. The proliferation of publications, seminars, conferences, and collective projects, inseparable from the funding and support invested in such subjects by public research institutions, prevents any facile overview of the works that have been generated. This is especially the case since, although its visibility was relatively low, the issue of nature was already central to the manifesto of science studies-at least as Latour had conceived the program based on his analysis of the relationship between science, technology, and politics. "If an anthropology of the [early] modern world were to exist, its task would consist in describing in the same way how all the branches of our government are organized, including that of nature and the hard sciences, and in explaining how and why these branches diverge as well as the many arrangements that bring them together," he wrote as early as $1991 .{ }^{36}$ At the same time and with the

Publications, 1994) in Dominique Pestre, "La production des savoirs entre académies et marché. Une relecture historique du livre: 'The New Production of Knowledge,' édité par M. Gibbons," Revue d'économie industrielle 79, no. 1 (1997): 163-74, republished as "La notion de régime de savoirs," in Pestre, Science, argent et politique. Un essai d'interprétation (Paris: INRA, 2003), 31-36. On the modern moment, see: Pestre, À contre-science. Politiques et savoirs des sociétés contemporaines (Paris: Éd. du Seuil, 2013); Pestre, ed., Le gouvernement des technosciences. Gouverner le progrès et ses dégâts depuis 1945 (Paris: La Découverte, 2014).

35. For a joint study of Philippe Descola and Bruno Latour, see Michel de Fornel and Cyril Lemieux, "Quel naturalisme pour les sciences sociales?" in Naturalisme versus constructivisme, ed. Michel de Fornel and Cyril Lemieux (Paris: Éd. de l'EHEss, 2007), 7-25. More broadly, see Alice Ingold, "Écrire la nature. De l'histoire sociale à la question environnementale ?" in "Environnement," ed. Alice Ingold, special issue, Annales HSS 66, no. 1 (2011): 11-29. Ingold notably highlights a change of paradigm in the relationship between the social sciences and nature: "the idea of a historical rupture in the relationship between societies and nature; the planetary dimension of ecological phenomena; and, finally, the previously unheard-of reflexivity of societies in their relationship to the environment" (p. 11). An idea of the abundance of studies published in this field can be gleaned from the eighty-three pages of reviews at the end of the special issue. This collection provides an excellent illustration of the domain's rapid expansion and its tendency to become increasingly autonomous, with a diversity of approaches matched by the diversity of spaces and periods covered.

36. Latour, We Have Never Been Modern, 15. In this essay, iconoclastic in both tone and subject matter, a paragraph is devoted to the "Crisis of the Critical Stance" and the "three distinct approaches to talking about our world: naturalization, socialization, and 
increased exposure that came from institutional recognition, nature found itself at the center of the French anthropological agenda, as attested by the creation of the chair in "Anthropology of Nature" at the Collège de France in 2001. Its holder, Philippe Descola, described the program as seeking "to understand the unity of humans through the diversity of the means they employ to objectify a world from which they cannot be dissociated." 37 The convergence of these various programs, which grew from very different origins, was accompanied by an increase in other types of studies, emanating from philosophers of science ${ }^{38}$ and other anthropologists outside France who, like Tim Ingold, set themselves the task of reformulating or surpassing the boundaries between nature and culture. ${ }^{39}$ These studies were fruitful and have undoubtedly contributed to the progressive emergence of interest in the environment, one of the areas in which the history of science and technology is currently undergoing its most evident forms of renewal.

For some, this issue has become the subject of a distinct type of history: environmental history. ${ }^{40}$ This field is central to the interpretation of our modern societies as risk societies. ${ }^{41}$ It takes up a new critique of industrial reason, associated

deconstruction" (p. 5). Naturalization is associated with the growth of neurobiology and with the work of Jean-Pierre Changeux, which is challenged by Latour's analysis. In the pages that follow and in his requalification of the notion of modernity, Latour relies on Descola's investigation.

37. Philippe Descola, Anthropology of Nature: Inaugural Lecture Delivered on Thursday 2 March 2001, trans. Liz Libbrecht (Paris: Collège de France/OpenEdition, 2014), 4. More broadly, see Descola, Beyond Nature and Culture, trans. Janet Lloyd (Chicago: University of Chicago Press, 2013). On Descola's undertaking, see the critical reading by Gérard Lenclud, "L'universalisme ou le pari de la raison. Note sur (et contre) le relativisme," in L'universalisme ou le pari de la raison. Anthropologie, histoire, psychologie (Paris: Gallimard, 2013).

38. Catherine Larrère, Les philosophies de l'environnement (Paris: Puf, 1997); Larrère, Du bon usage de la nature. Pour une philosophie de l'environnement (Paris: Aubier, 1997); Larrère, "La question de l'écologie. Ou la querelle des naturalismes," in "Naturalismes d'aujourd'hui," special issue, Cahiers philosophiques 127 (2011): 63-79, which also includes an interview with Descola; and Jean-Marc Drouin, L'écologie et son histoire: réinventer la nature (1991; repr. Paris: Flammarion, 1999).

39. Tim Ingold, "Human Worlds are Culturally Constructed: Against the Motion (1)," in Key Debates in Anthropology, ed. Tim Ingold (London: Routledge, 1996), 112-18; Ingold, "Eight Themes in the Anthropology of Technology," Social Analysis: The International Journal of Social and Cultural Practice 41, no. 1 (1997): 106-38; Ingold, "Hunting and Gathering as Ways of Perceiving the Environment" and "Building, Dwelling, Living: How Animals and People Make Themselves at Home in the World," in The Perception of the Environment: Essays on Livelihood, Dwelling and Skill (London: Routledge, 2000), respectively $40-60$ and $172-88$.

40. Fabien Locher and Grégory Quenet, eds., "Histoire de l'environnement," special issue, Revue d'histoire moderne et contemporaine 56, no. 4 (2009); Jean-Baptiste Fressoz et al., Introduction à l'histoire environnementale (Paris: La Découverte, 2014); and Grégory Quenet, Qu'est-ce que l'histoire environnementale? (Seyssel: Champ Vallon, 2014).

41. Jean-Baptiste Fressoz, L'apocalypse joyeuse. Une histoire du risque technologique (Paris: Éd. du Seuil, 2012); Christophe Bonneuil and Pierre-Benoît Joly, Sciences, techniques et société (Paris: La Découverte, 2013), notably pp. 29-38; François Jarrige, Technocritiques. Du refus des machines à la contestation des technosciences (Paris: La Découverte, 2014). 
with the critique of technological reason and echoing the contemporary deindustrialization of Western societies. ${ }^{42}$ It is nourished by a sizeable group of studies on the climate, focusing on its place in the modern world or on the possible ways of conceptualizing its history. ${ }^{43}$ As a new subject of the history of science, the climate encourages practitioners of the discipline to reconsider an issue traditionally studied by historians and philosophers: temporality. This is clear in the work of Dipesh Chakrabarty, a historian from India based at the University of Chicago, who proposes inscribing the study of these questions within a framework of chronologies drawn from earth science. ${ }^{44}$ Indeed, if "the climate crisis ... produces problems that we ponder on very different and incompatible scales of time," then, to put it briefly, we should introduce a new scale into our analyses, one that is "planetary" as distinct from "global," and which displaces the resolutely anthropocentric approaches of the social sciences. ${ }^{45}$ Thus Chakrabarty, who fifteen years ago encouraged historians to "provincialize" Europe, now encourages us to go one step further in the scales of provincialization: the issue is now the globe itself, which has become a province in relation to the universe. ${ }^{46}$

This work joins the radical critique of historical reason by historians from other historiographical traditions, such as Harvard professor David Armitage, a specialist in the intellectual history of early modern imperial ideologies who has recently taken up the defense of the longue durée in his "manifesto" for history. ${ }^{47}$ It also ultimately echoes a broader movement among historians to explore connections between disciplines that are currently either desirable or fruitful. Some of

42. See notably the following studies on pollution: Geneviève Massard-Guilbaud, Histoire de la pollution industrielle. France (1789-1914) (Paris: Éd. de l'EHEss, 2010); Thomas Le Roux, Le laboratoire des pollutions industrielles. Paris, 1770-1830 (Paris: Albin Michel, 2011).

43. On the historical aspect, see the special issue "Climat et histoire, XVI ${ }^{\mathrm{e}}-\mathrm{XIX} \mathrm{e}^{\mathrm{e}}$ siècle," Revue d'histoire moderne et contemporaine 57, no. 3 (2010), particularly Emmanuel Garnier, "Fausse science ou nouvelle frontière? Le climat dans son histoire," 7-41. On the problems of modeling, see Amy Dahan Dalmedico, ed., Les modèles du futur. Changement climatique et scénarios économiques : enjeux scientifiques et politiques (Paris: La Découverte, 2007).

44. Dipesh Chakrabarty, "The Climate of History: Four Theses," Critical Inquiry 35, no. 2 (2009): 197-222; Chakrabarty, "Climate and Capital: On Conjoined Histories," Critical Inquiry 41, no. 1 (2014): 1-23. The latter article opens with the following declaration: "Anthropogenic global warming brings into view the collision-or the running up against one another-of three histories that, from the point of view of human history, are normally assumed to be working at such different and distinct paces that they are treated as processes separate from one another for all practical purposes: the history of the earth system, the history of life including that of human evolution on the planet, and the more recent history of industrial civilization (for many, capitalism)."

45. Ibid., 3-4.

46. Chakrabarty, Provincializing Europe: Postcolonial Thought and Historical Difference (Princeton: Princeton University Press, 2000).

47. Jo Guldi and David Armitage, The History Manifesto (Cambridge: Cambridge University Press, 2014), discussed in the dossier of articles on the longue durée published in this issue of the Annales, pp. 219-303. 
these propositions extend well beyond the social sciences. Life science and particularly biology have attracted historians and anthropologists at regular intervals-as attested by the debate on sociobiology in the $1970 \mathrm{~s}^{48}$ and the current debate on neuroscience ${ }^{49}$ involving doctors, psychologists, sociologists, biologists, chemists, mathematicians, and computer scientists, which has led to the emergence of a new paradigm: the "social neurosciences." 50 The small step from the social neurosciences to neurohistory was taken by Daniel Lord Smail's book On Deep History and the Brain, and in recent years its echoes can be observed not only among specialists in the social sciences but also among some historians. ${ }^{51}$

The proximity between studies of the environment and sciences devoted to nature and the earth feeds into the critique of anthropocentrism in both its European and global—or rather, planetary_dimensions. In so doing, it risks putting an end to the historicization of the questions we ask about nature and referring them back to the regimes of temporality generated by the natural sciences. ${ }^{52}$

Have we thus reached the limits of the dialogue between the sciences of nature and the earth and the sciences of man and society? The question merits discussion, since, beyond the environment, other subjects present similar characteristics as soon as one begins to consider the possibility of a collaboration between the social and natural sciences. Here again, it is necessary to explore the multiple genealogies behind the current connections, an undertaking that would undoubtedly lead to the rediscovery of the epistemology of science in the tradition of Georges Canguilhem and Michel Foucault. ${ }^{53}$ It would also remind us of the multiple

48. Marshall Sahlins, The Use and Abuse of Sociobiology: An Anthropological Critique of Sociobiology (Ann Arbor: University of Michigan Press, 1976).

49. By way of an example, see the special dossier "Roundtable: History Meets Biology," American Historical Review 119, no. 5 (2014): 1492-1629.

50. Wolf Feuerhahn and Rafael Mandressi, eds., "Les sciences de l'homme à l'âge du neurone," special issue, Revue d'histoire des sciences humaines 25 (2011); Andrew Shryock and Daniel Lord Smail, eds., Deep History: The Architecture of Past and Present (Berkeley: University of California Press, 2011).

51. Daniel Lord Smail, On Deep History and the Brain (Cambridge: Harvard University Press, 2008). For an example, see the special issue "Traduire et introduire," Tracés. Revue de sciences humaines 14 (2014). Part of this issue is devoted to Smail, notably the critical reading by Rafael Mandressi, "L'historien, le cerveau et l'ivresse des profondeurs," 113-26.

52. And thus the divide between these approaches and those working with social actors widens. See: Richard H. Grove, Green Imperialism: Colonial Expansion, Tropical Island Edens and the Origins of Environmentalism, 1600-1860 (Cambridge: Cambridge University Press, 1995); Londa Schiebinger and Claudia Swan, eds., Colonial Botany: Science, Commerce, and Politics in the Early Modern World (Philadelphia: University of Pennsylvania Press, 2005), especially the article by Marie-Noëlle Bourguet, "Measurable Difference: Botany, Climate, and the Gardener's Thermometer in Eighteenth-Century France," 270-86; and Neil Safier, Measuring the New World: Enlightenment Science and South America (Chicago: University of Chicago Press, 2008).

53. Jean-François Braunstein, ed., Canguilhem. Histoire des sciences et politique du vivant 
contiguities between the subject of "nature" and the subject of "mankind," and of the degree to which these areas of contact are likely to open up productive new questions for the history of science. Once again, this was demonstrated from the early 1990s, when Donna Haraway's work constructed a new bridge between gender studies and the technosciences. ${ }^{54}$

These few milestones, marking out some lines of thought to pursue and a history that remains to be written, suggest the considerable widening of the domain of the "history of science," a widening that has both enriched and fragmented the field. New temporalities and spatialities are mobilized according to readings that are specific to our society, within which they are inscribed and to which they refer.

\section{Ceremonies of Measurement versus the Grand Narrative of Modernity}

Schaffer's work over the long term since Leviathan and the Air-Pump points toward a number of the questions I have raised. But he has also shaped these interrogations, as attested by his role as a reference point for many of the studies cited here. In a general sense, studies of controversies have gained a place well beyond the field of science and technology, having long left the British landscape and the "airpump" and moved on to all periods and subjects. The analysis of material, literary, and social technologies that was employed in Leviathan has also gained new territory and continues to enhance our understanding of the social production of knowledge. But at the moment when they were perfected and tested, these technologies also aimed to put an end to the "grand narrative of modernity." This is the point on which I would like to focus here, since this "grand narrative" is more central than ever in current debates-especially if Chakrabarty and Armitage's propositions are considered as its ultimate critique. The very expression mobilizes two distinct questions: that of the grand narrative and that of modernity. These are not unrelated, of course, but dissociating them here will help provide some clarity on the issues and the debates borne by the new history of science.

\section{Making Sense of World Polycentrism}

Following on from two of his previous articles, the text on ceremonies of measurement that Schaffer has published in this issue of the Annales demonstrates the

of particular interest for the observations made in this article. See also Simon Schaffer, "How Disciplines Look," in Interdisciplinarity: Reconfiguration of the Natural and Social Sciences, ed. Andrew Barry and Georgina Born (London: Routledge, 2013), 57-81.

54. Donna Haraway, Simians, Cyborgs, and Women: The Reinvention of Nature (New York: Routledge, 1991); Haraway, "A Manifesto for Cyborgs: Science, Technology, and Socialist Feminism in the 1980s," and the other essays collected in The Haraway Reader (New York: Routledge, 2004); and Haraway, The Companion Species Manifesto: Dogs, People, and Significant Otherness (Chicago: Prickly Paradigm Press, 2003). 
engagement with the "faraway" that has become central to his research over the last ten years. One could effectively consider this article as echoing both "Newton on the Beach," which charts the global networks that converge in the Principia mathematica, ${ }^{55}$ and "The Asiatic Enlightenments of British Astronomy," which investigates the Asian sources that made Newton a scholarly reference in India in the 1780s. ${ }^{56}$ By focusing on the personality and the work of Tafazzul Husain Khān, who first translated the Principia into Arabic in Bengal in 1789, Schaffer notably sought to highlight the complexity of the translation practices at work in the circulation of Newton's texts in this part of the world. At the same time, he pointed to the various interpretations of Newton, as much on the part of colonial administrators as on that of the Indo-Persian scholars with whom scientific collaborations were established and intensified. ${ }^{57}$ This article, fed by a close dialogue with Kapil Raj, ${ }^{58}$ is based on a long-term study of both the archives and the abundant historiography concerning the Asiatic Society, founded in 1784. Without retroactively inventing a sense of continuity, it could be suggested that all three texts share in and construct the same itinerary: if there is no single History of how science has been made but rather many histories, these are to be found in a scattered and diverse group of scenes in which the issue of translation is played out, each time in a different way. In one case, it involves Newton's Principia; in another, it concerns the science of measurement, directly issued from the conceptual matrix of Newtonian physics.

In all three articles, the narrative structures are comparable. Schaffer displaces the certainties inherited from the grand narrative of early modern science: for scholars in the burgeoning British Empire, regular visits to India and familiarity with its history and sources made it possible to assert that Buddhism and Newtonianism were a single science with the same global origins. ${ }^{59}$ The "Newtonian revolution" was not accomplished in an office, nor did the emergence of metrology produce a pure science that would at last be exempt from ritual. ${ }^{60}$ These histories support the powerful argument that procedures of mediation provide a better understanding of the multiplicity of interlaced elements through which the kaleidoscope of the early modern world emerged. Consequently, the history of early modern science may be understood as a process of intermediaries or "go-betweens," to borrow the title of the 2009 volume containing the article devoted to Tafazzul.

55. Simon Schaffer, "Newton on the Beach: The Information Order of Principia Mathematica," History of Science 47 (2009): 243-76. Translated in La fabrique des sciences as "Newton à la plage : l'ordre de l'information dans les Principia mathematica," 15-54. The title is borrowed from that of an opera by Philip Glass, directed by Robert Wilson in 1976: Einstein on the Beach.

56. Schaffer, "The Asiatic Enlightenments of British Astronomy," in The Brokered World: Go-Betweens and Global Intelligence, 1770-1820, ed. Schaffer et al. (Sagamore Beach: Science History Publications, 2009), 49-104.

57. Ibid., 51. On Tafazzul, see p. 53.

58. Kapil Raj, "Mapping Knowledge Go-Betweens in Calcutta, 1770-1820," in Schaffer et al., The Brokered World, 105-50.

59. Schaffer, "The Asiatic Enlightenments," 53. 
When put into perspective, these three texts reflect a reorientation in the intellectual trajectory of Schaffer, as it moved away from the Royal Society in London and the history of science during the Enlightenment. ${ }^{61}$ This inflection led him to read Newton differently and from another center of gravity, considering the ways that different kinds of actors used the scientist and sometimes reading his work in the same way and on the same level as other sources that were more iconoclastic for a historian of science. Schaffer's "beach" indicates the need to inscribe the examination within an extended geography of the world. It points to an epistemology of science that investigates small arrangements between practitioners belonging to different social orders and different worlds and the mobilization of the vast global theatre for making sense of them.

This shift runs parallel to the one that has taken place in other fields of research over the last twenty years, as recent historiography has broken down the barrier raised up by earlier studies on the grand narrative of early modern science. This barrier confined the examination solely to the London-Paris axis, relegating all other spaces in Europe and, to an even greater extent, the rest of the world to the non-places and unspoken realm of the "periphery"-whether geographical, ${ }^{62}$ chronological, ${ }^{63}$ or disciplinary. ${ }^{64}$ One is thus obliged to admit that the legacy of

61. William Clark, Jan Golinski, and Simon Schaffer, eds., The Sciences in Enlightened Europe (Chicago: Chicago University Press, 1999). For an overview of Schaffer's trajectory, see Stéphane Van Damme, "Laborious Nature: Simon Schaffer and the History of Science," trans. Michael C. Behrent, Books\&ideas.net, published March 23, 2015: http:// www.booksandideas.net/Laborious-Nature.html.

62. The center/periphery paradigm was synthesized in the 1960s by Georges Basalla, "The Spread of Western Science," Science 156, no. 3775 (1967): 611-22. Since then, the increase in research on other European spaces should be noted. For studies of Iberian and Italian Catholicity conducted over the last ten years, see in particular: Jorge Cañizares-Esguerra, Nature, Empire, and Nation: Explorations of the History of Science in the Iberian World (Stanford: Stanford University Press, 2006); Daniela Bleichmar et al., eds., Science in the Spanish and Portuguese Empires, 1500-1800 (Stanford: Stanford University Press, 2009); Antonella Romano, ed., Rome et la science moderne entre Renaissance et Lumières (Rome: École française de Rome, 2008); and Elisa Andretta, Roma medica. Histoire d'un système médical au XVI siècle (Rome: École française de Rome, 2011). More broadly, the geographies of knowledge production have been at the heart of an abundance of research, which has contributed to decentering the questions posed and the areas examined: Harold J. Cook, Matters of Exchange: Commerce, Medicine, and Science in the Dutch Golden Age (New Haven: Yale University Press, 2007); Feza Günergun and Dhruv Raina, eds., Science Between Europe and Asia: Historical Studies on the Transmission, Adoption and Adaptation of Knowledge (New York: Springer, 2011); and László Kontler et al., eds., Negotiating Knowledge in Early Modern Empires: A Decentered View (New York: Palgrave Macmillan, 2014).

63. The mathematical primacy of Renaissance Italy came to an end with the country's peripheralization as soon as it ceased to produce figures such as Galileo. As a consequence, Italy provided its European audience with a model of pantheonization where the heroes of "modern science" were transformed into the new martyrs of backward societies. The "Black Legend" that haunted the Iberian peninsula was deeply associated with the story of its inability to have jumped on the train of modernity at the right moment. 64. The model of the scientific revolution was also a physico-mathematical one, as highlighted above. Modernization was therefore measured against the growth of this 
the history of science as a history of ideas contributed to the development of one of the main lacunae occulted by this history: its situatedness in space. In this way, the center-periphery pairing has functioned as the implicit reference of the dynamics mobilized by the model of the scientific revolution. Even after research was directed toward empires within the context of the international "Science and Empires" program, this pairing continued to play a decisive role. Its trace can be found in the first publications associated with this program and even before, in the following question posed by Needham:

That Chinese discoveries and inventions there were, we have long known; that they were transmitted one after the other to Europe, we can demonstrate or know to be extremely likely; but the extraordinary paradox arises that while many, even most, of them had earth-shaking effects upon occidental society, Chinese society had a strange capacity for absorbing them and remaining relatively unmoved. ${ }^{65}$

Only recently has a critical reexamination of the "Needham question" led to a shift in the study of science in non-European worlds, introducing the perspectives of locality and circulation. ${ }^{66}$ In another register and according to different methods and calendars, research on the various parts of Europe and their role in the development of science, technology, and knowledge in the early modern era has not only hastened the reformulation of our comprehension but also raised our awareness of other spatial and thematic connections. ${ }^{67}$

Today, the historiographical landscape of modernity is infinitely more mixed and new regions continue to be explored according to a dual movement that leads them to feed off and into each other, with new investigations strongly contributing to deconstructing the idealized and imaginary Europe of the scientific revolution. The political, linguistic, social, and religious heterogeneity of that part of the world-now reenvisioned by some as the furthest reach of the Eurasian landmass-encourages scholars to measure the early modern period from the perspective of a broader spatialization which points toward a polycentric world. Furthermore, by increasing the range of areas examined, these studies have also altered the questions that are posed, considering fields other than those we call "the

field, according to the rationale of a teleological vision of history that saw a continuity between the "scientific revolution" and the "industrial revolution." The shift from research into the physico-mathematical sciences toward questions about the natural sciences was therefore crucial in the reconfiguration of research agendas over the last thirty years, and has increasingly gathered speed since the early 2000s.

65. Joseph Needham, The Grand Titration: Science and Society in East and West (1969; repr. London: Routledge, 2013), 61-62. For a critical reading, see Kapil Raj, "Rescuing Science from Civilisation: On Joseph Needham's 'Asiatic Mode of (Knowledge) Production," in The Bright Dark Ages: Comparative and Connective Perspectives, ed. Arun Bala and Prasenjit Duara (Leiden: Brill, 2016), 255-80.

66. In this respect, see the compilation of articles by Kapil Raj, Relocating Modern Science: Circulation and the Construction of Knowledge in South Asia and Europe, 1650-1900 
sciences" today. Reinserted into relationships which more closely resemble the grammar of early modern knowledge, natural history, cartography, and medicine now occupy a central place on the agenda of historians of science. While the list of these studies urging us to take a different look at the early modern period is decidedly too long, it nonetheless confirms that, by adopting diverse paths and approaches, they are shaking up the grand narrative of modernity centered on Europe. In particular, they have given their own centrality over to the colonies as laboratories of European science, underlining its imperial aspect and revealing the multiple circulations on which it depended.

\section{Science between Newton and Gulliver}

These studies have brought a whole new scale of analysis to bear: that of the globe, which, without eliminating other scales, often leads to their reordering. Schaffer's research makes use of both the local and the global scale. "These essays," he writes, "suggest that scientific knowledge is often constructed in a local and trivial way, that it relies not only on particularly brilliant or rational methods but also on efforts of persuasion and credibility." 68 The charm of the history of metrology as proposed in "Ceremonies of Measurement" thus rests on its trivial, anecdotal nature. Schaffer lays out parallel itineraries leading from Guinea or Senegal to Venice or Basel by way of Nuremberg or Lagado, real and fictional places distributed between Europe, Africa, Asia, and within literature. By following these bypaths and backstreets, he little by little sketches out a framework for what he calls the "world history of sciences." Attention should be paid to the fact that, in this text at least, the history called upon only seems to be legitimized by the choice of subject, the centering of the reflection on the "worldly extension of measurement practices": "The concern in this article is to use these stories of mediations and rituals as ways of reflecting on the worldly extension of measurement practices and thus on that of the science of these practices, metrology." 69

It is thus a proposal for a world history of science that is primarily a history of its "worldly extension," in which the scale of analysis seems to preexist the object studied. This raises an initial question: is this extension the single issue of a world history of science, and would the history of science then become a world history with the emergence of worldwide scientific practices? If that is what is being proposed, it deserves to be examined and, a fortiori, to be made explicit. This would enable it to be compared with other ways of thinking about knowledge production as it is articulated along various scales and according to other chronologies or perspectives. To the contrary, in this text Schaffer does not make reference to global history-such silence is undoubtedly a deliberate choice which begs for clarification since it implies a rejection. ${ }^{70}$ Among the many ways in which the global

68. Schaffer, preface to La fabrique des sciences, 8 .

69. Schaffer, "Ceremonies of Measurement," 336.

70. Ibid., 348: "It is not my aim here to pursue the ambitions of this universal ethnography of a globally diffused ritual system." 
scale is used, one stands out, establishing it as a tool aiming to compare and even combine the effects of the knowledge it produces with that produced by other scales. In this sense, the history of "worldly extension" could be one of the histories that is used to grasp the complexity of the exchange between actors, most certainly local and situated but also inscribed within other circuits of exchange and depending on other stories unrelated to that extension.

Among the issues raised by a reading of Schaffer are the questions posed by historians more generally: scales of analysis, the use of case studies, comparativism, and histoire croisée or connected history-not as part of a unified paradigm of the type generated by the Annales but in the multiple and contradictory directions opened up by the "critical turn" of the late 1980 s. $^{71}$ Reading this work and that of other historians of science, one is surprised by the distance between the two approaches, as though-in spite of all the shifts that may be identified in their research programs - these scholars still had to show the uniqueness of their method. Yet a broad convergence between history and the history of science is more necessary than ever. It is the only way to avoid a rift between a retrospective narrative framing the history of the early modern world as one of globalization, and the many narratives-voiced through various case studies and too hastily likened to microhistory_of alternative ways of shaping the social through knowledge and technologies.

In Schaffer's recent studies, the worldly scale and its capacity to reveal the extension of practices and norms arises from a particular time and place. This is Britain, that tiny fraction of Europe which, during the ascendant phase of its imperial project, found itself the bearer of dynamics leading to the emergence of new forms of knowledge and scientific and technological production through which modernity imposed itself on the world. At the moment when, as my brief survey

71. In the decade following the publication of Jacques Revel, ed., Jeux d'échelles. La micro-analyse à l'expérience (Paris: Gallimard/Seuil, 1996), which grew out of a research seminar at the EHESS, investigations and debates multiplied in France, raising the issues of scales and methods. As a reminder, the propositions of histoire croisée (intersecting history) and histoires connectées (connected histories) developed at the same time. In 2001, the first issue of Annales HSS 56 contained two collections of articles. The first, entitled "Une histoire à l'échelle globale. Braudel et l'Asie," was composed of an article by Roy Bin Wong ("Entre monde et nation: les régions braudéliennes en Asie," pp. 5-41) and an article by Maurice Aymard ("De la Méditerranée à l'Asie: une comparaison nécessaire [commentaire]," pp. 43-50), adopting an economic perspective. The first of these articles has since been translated into English: Roy Bin Wong, "Between Nation and World: Braudelian Regions in Asia," Review (Fernand Braudel Center) 26, no. 1 (2013): 1-45. The second dossier of articles was called "Temps croisés, mondes mêlés" and brought together an article by Sanjay Subrahmanyam ("Du Tage au Gange au XVI ${ }^{\mathrm{e}}$ siècle: une conjoncture millénariste à l'échelle eurasiatique," pp. 51-84) and an article by Serge Gruzinski ("Les mondes mêlés de la Monarchie catholique et autres "connected histories," pp. 85-117), which were in turn discussed by Roger Chartier ("La conscience de la globalité [commentaire]," pp. 119-23), from a cultural point of view. During the same period, the following collective volume raised the issue of scales of analysis in distinct terms: Michael Werner and Bénédicte Zimmermann, eds., De la comparaison à l'histoire croisée (Paris: Seuil, 2004). 
has shown, all kinds of investigations into science and knowledge are multiplying in all kinds of contexts, and studies concerning all parts of the globe, all actors, objects, and sources, are becoming relevant, what is the significance of Schaffer's exercise in identifying "worldly extension"? In relating the infinite variety of ceremonies of measurement to the only one that triumphed-the European one-do we not risk losing sight of the meaning, validity, and purpose of all the others? In particular, what about those that were able to function elsewhere in time and space as standards setting the measurement of exchange? In other words, what should one do with the tales that did not enter into the process connecting Newton to India?

In the introduction to the collection of his articles recently translated into French, Schaffer writes that "these stories essentially took place in Western Europe, primarily Great Britain and France," and extend to other spaces as "the reader is invited to take a trip" to the Americas, Asia, and elsewhere. ${ }^{72} \mathrm{He}$ thus reminds us of his own itinerary, which began with his early research on Europe-between London and Paris - and then extended to the world beyond. By working on early modern science, Schaffer was retracing the construction of modernity, even though he used a different index than the alignment of geniuses on an arc describing progress and its propagation throughout the world. Through his choice of guiding thread, the phenomenon he studies is not only identified with systems of knowledge of which the validity was constructed through the controversies that occupied European scholarly circles. It is also associated with the history of Britain and the advent of its empire during the Enlightenment. Thus, by choosing to follow the trail of Newtonian astronomy, even in the most exotic places and through its most unexpected variations (for instance, by using India to connect the Newtonian project of natural philosophy to that of natural theology, and to reread the two together ${ }^{73}$ ), is Schaffer not effectively continuing his examination of modernity associated with the production of early modern science, even if it is from a fresh perspective? The production of early modern science is not challenged as a relevant category of analysis, and continues to be tasked with shedding light on the advent of modernity, notably through one of its most important variations at the geopolitical level: globalization.

\section{An Archaeology of Scientific and Technical Knowledge}

An initial return to Europe between the sixteenth and eighteenth centuries suggests that the work of both scholars and intermediaries in science was mobilized as much by botanical surveys and projects to decipher the languages of the world as by astronomical observations. In this respect, the focus of Schaffer's research on the field of astronomy suggests two questions: Has worldly extension only followed the paths of early modern physics and metrology, and should the worldly extension of measurement practices be considered its only or even central 
pillar? Answering this question encourages, for example, a consideration of the gestures shared by astronomers, botanists, and philologists at a time when their practices and nascent professional identities had yet to be separated from one another, and their relationship to objectivity remained to be stabilized. ${ }^{74} \mathrm{We}$ also know that other genealogies of modernity have been proposed, as suggested by Foucault, who followed a distinctly different thread from that of natural philosophy. This returns us to another question, involving the status that Schaffer assigns to the physico-mathematical sciences in relation to other fields that are less explored in his work.

Yet Schaffer was familiar with Foucault's corpus, and its influence can be felt in his interest in instruments and technologies. ${ }^{75}$ His research on metrology is part of this genealogy, for the science he aims to describe does not exist without the world of artisans, instrument makers, and inventors working alongside chemists, doctors, jurists, and theologians. ${ }^{76}$ As he clearly stated in another article, "the traditional boundaries between epistemology and practice" should be "questioned." 77 As a historian of both science and technology, Schaffer reflects more broadly on the role of "technology" in the establishment of early modern science and offers a conclusion of a similar magnitude:

Social technologies organize workers to make meaningful measurements; material technologies render specific phenomena measurable and exclude others from consideration; literary technologies are used to win the scientific community's assent to the significance of these actions. Such episodes indicate how these technologies work together. The formation of a discipline is simultaneously the process of organizing work to produce these values and the system of knowledge which gives the values their meaning. ${ }^{78}$

74. Sheldon Pollock, "Future Philology? The Fate of a Soft Science in a Hard World," Critical Inquiry 35, no. 4 (2009): 931-61.

75. Schaffer discovered Foucault earlier than his anglophone colleagues, while staying in Paris in the early 1980s and attending classes at the Collège de France. See the interview with Schaffer published as "Taxonomie, discipline, colonies: Foucault et la Sociology of Knowledge. Entretien avec Simon Schaffer," in Bert and Lamy, Michel Foucault, 363-74, especially pp. 364-65.

76. Schaffer, "Measuring Virtue: Eudiometry, Enlightenment and Pneumatic Medicine," in The Medical Enlightenment of the Eighteenth Century, ed. Andrew Cunningham and Roger French (Cambridge: Cambridge University Press, 1990), 281-318. Translated in La fabrique des sciences as "Mesurer la vertu: eudiométrie, Lumières et médecine pneumatique," 217-57.

77. Schaffer, "Experimenters' Techniques, Dyers' Hands, and the Electric Planetarium," Isis 88, no. 3 (1997): 456-83, citation p. 483. Translated in La fabrique des sciences as "Les techniques de l'expérimentateur, les mains du teinturier et le planétarium électrique," 171-216.

78. Schaffer, "Astronomers Mark Time: Discipline and the Personal Equation," Science in Context 2, no. 1 (1988): 115-45, here p. 118. Translated in La fabrique des sciences as "Quand les astronomes marquent leur temps. Discipline et "équation personnelle," 259-97. It should be noted that this is one of the oldest articles published in the French volume. 
The proximity to Foucault is undoubtedly located within this continually renewed investigation into technology, which imposes its discipline upon both the worker's body and the social body. ${ }^{79}$ Yet, as Schaffer now indicates about his earlier studies, what remained was "to know whether biopolitics existed for the hard sciences, for the field sciences, for the science of travel. ... It was a question ... of reintroducing the knowledge/power dyad and understanding the murderous effects of the physics of power." 80 The modernity Schaffer investigates is that which allows him to retrace the advent of capitalism. In the preface to La fabrique des sciences, he situates his analysis within "a pivotal moment: the advent of capitalism and its development in the four corners of the world - a development undoubtedly limited by the events of this period." ${ }^{81}$ His history of measurement rituals marks a new step in this direction, for by its very nature the "new science" of metrology, relying on a group of technologies, supported the growth of capitalism-which would later become the ultimate subject of its study.

I would like to underline the extent to which Schaffer, by affording technology such an important place in his examination, has opened up fruitful paths toward understanding the social mechanisms that contribute to making the world. Not only has he begun the recomposition of the "history of science" by ridding it of the old division between science and technology, he has also laid the groundwork for a necessary dialogue with historians of economics - at least that is the hypothesis I would like to formulate here. ${ }^{82}$ The current climate within the social sciences is characterized by the fact that economic historians, confronted with the challenges of modern globalization, are also ready to rethink the grand narrative of the industrial revolution and the advent of capitalism in a variety of ways, some through a rereading of European history and others by situating themselves immediately on the global scale. ${ }^{83}$ A closer dialogue between historians of science and historians of economics would undoubtedly make it possible to articulate transformations in science and technology with changes in capitalism in new terms.

Let me give an example. With his theory of a Great Divergence, Kenneth Pomeranz has suggested the existence of an economic model that is at once development-based and non-capitalist. While this is not the place to reassess this

79. Ibid.

80. Schaffer, "Taxonomie, discipline, colonies," 371.

81. Schaffer, preface to La fabrique des sciences, 7.

82. It would take more than a single article to lay out the history of these relations, which is made up of profound divergences and projects for alliances. The research program known as "Science, Technology, and Society" constitutes the most recent example, in the model of the study of "technosciences."

83. For an example of the former current, see Jan de Vries and his approach to the technological mutations of early modern Europe in terms of an "industrious revolution": Jan de Vries, The Industrious Revolution: Consumer Demand and the Household Economy, 1650 to the Present (Cambridge: Cambridge University Press, 2008). For the latter, see Kenneth Pomeranz, The Great Divergence: China, Europe, and the Making of the Modern World Economy (Princeton: Princeton University Press, 2000), which reopens "Needham's question." 
widely debated work, Pomeranz can be understood to be reflecting on a history of technology that does not seem to be indexed with modernity and whose economic and social order does not find its ultimate expression in capitalism. From this point of view, the early modern period-reduced to a division of history whose relevance and limits would have to be redefined-offers today's world open horizons for research. It encourages us to historicize the development of capitalism and to frame it within a plurality of regimes of production in which other alliances between knowledge, technology, and societies have been possible. The history of China during the Ming and Qing periods provides resources and a rapidly expanding historiography that make it possible to envision other convergences and divergences, as the article that Schaffer published in the Annales in 2005 indicates. ${ }^{84}$

\section{Recounting the Histories of the Sciences}

The final question that Schaffer's work prompts us to ask concerns the ousting of the grand narrative. This preoccupation can be observed throughout his work, primarily in his preference, since the publication of Leviathan in 1985, for articles over books. In his introduction to La fabrique des sciences, Shaffer is careful to explain that he proposes "a collection of short stories or 'histories,' not a sweeping saga" 85 in order to construct the "histories of the sciences"- a plural that is taken up in the title of the volume. Indeed, all of his studies share the same concern, which is also an epistemological choice. They aim to make explicit his refusal of the "incredibly widespread idea ... that science obeys a single method and progresses in an even way-the reason that historians of science are usually expected to write this rectilinear course, marked by scientific progress and the triumph of moral values, into their work." 86 In its place, he sets the historian of science a different task: "to familiarize the reader with the notion of 'strangeness' by offering tales presenting other worlds and other peoples, excluded from the domain of reason by force, silence, or disdain." ${ }^{87}$ In "Ceremonies of Measurement," the rejection of the idea of a linear and Eurocentric production of metrology is borne up by a precise literary technology: an assembly of scenes linked to one another in a kaleidoscope that reveals those other worlds that have been excluded.

This is one of the major strengths of Schaffer's work. He is concerned with giving a voice back to those who have been silenced by history, not only to the

84. Simon Schaffer, "L'inventaire de l'astronome. Le commerce d'instruments scientifiques au XVIII" siècle (Angleterre-Chine-Pacifique)," Annales HSS 60, no. 4 (2005): 791-815. It is worth recalling the mission statement of this article, set out on p. 791: "Two aspects of the use of instruments are envisioned here: by constructing knowledge, they act as mediators between the world and their users; by elaborating communities of knowledge, they mediate between various users. The history of science has recently sought to demonstrate the articulation between these two uses, since the question of knowledge is related to the social order."

85. Schaffer, preface to La fabrique des sciences, 7. 
European artisans who featured in his history of scientific instruments but also to those who have appeared on the multiple stages of the world's theater. However, this desire-already formulated by Antonio Gramsci in the 1920s—is not matched by a consideration of the nature of these tales, whose origins may lie in distant lands but which are, for the most part, recorded in almost exclusively Western sources and mobilized in an investigation whose priorities are defined by European history-as is the case in "Ceremonies of Measurement." In the spaces Schaffer explores at least, the distribution of both sources and voices is unequally shared and, even if he introduces many actors into a story that thus becomes a history of science, the voices and actions of these actors nonetheless do not have the same weight, legitimacy, or traceability. It is essential to acknowledge that the extent to which their traces have been erased varies depending on moments, spaces, and types of encounters as well as according to the places from which the practices of intermediation are observed. The scenes are arranged in a particular way and the kaleidoscope is moved, in one sense or another, by the narrator-just as it was in the public spectacles that Schaffer was one of the first to place at the heart of the history of science. ${ }^{88}$ How far can the parallel with literature be taken?

Some of these histories analyze the "spectacular" aspect of the scientific adventure in the fairgrounds and theaters of the eighteenth century or in the observatories and factories of the nineteenth century. It is important to show that the making of knowledge and its social status have a supremely "spectacular" aspect and that this "representation" of knowledge occurs all along the permeable frontiers that delimit scientific institutions. ${ }^{89}$

The "short stories" or histories ${ }^{90}$ through which the obstacle of the grand narrative of science is avoided and its legitimacy definitively dismissed are thus mobilized as a method in the work itself. That is what leads Schaffer to travel along with his readers, rather like the Enlightenment authors who spoke of the foreign (fictional or real) in order to better speak about themselves. Jonathan Swift joins François Bernier and Montesquieu in his repertory of references. ${ }^{91}$ The reference to literary texts is also evidence of a particular model of writing and its processes. The humorous tone adopted by Schaffer, which in no way sacrifices the seriousness of his references or a precise and rigorous knowledge of his sources, could also be an echo of the choices made by those of his predecessors now identified as the founding figures of modernity - whereas scholars who write a critical history of the world as a history of its modernization through science have generally opted to set aside Gulliver's Travels. Or at least that is one possible hypothesis. Irony also appears

88. Schaffer, "Natural Philosophy and Public Spectacle in the Eighteenth Century," History of Science 21, no. 1 (1983): 1-43. Translated in La fabrique des sciences as "La philosophie naturelle et le spectacle public au XVIII ${ }^{\mathrm{e}}$ siècle," 115-70.

89. Schaffer, preface to La fabrique des sciences, 11-12.

90. Ibid., $7 \mathrm{ff}$.

91. Schaffer refers to Gulliver's Travels by Jonathan Swift (1726), Travels in the Mogul Empire A.D. 1656-1668 by François Bernier (1699), and Persian Letters by Montesquieu (1721). 
here as the last resort of a marginal group of European intellectuals, who during the Enlightenment found it a fitting way to critique their own Eurocentrism. This included Swift, of course, as well as Montesquieu and his Persian Letters. It allowed for the condemnation of Eurocentrism by Europeans themselves.

Even so, and supposing that such a reading is relevant, the notion that the historian's task is ultimately to produce histories remains a debatable proposition. Schaffer's explicit reference to Sanjay Subrahmanyam's work acts as an important indicator here: "Modernity is historically a global and conjunctural phenomenon, not a virus that spreads from one place to another." 92 The grand narrative, associated with a linear and diffusionist interpretation of innovations produced in Europe, disappears before "vignettes" and local scenes; for Schaffer the historian's task is to show the various ways these local scenes sketch out the connections mobilized by particular agents, intermediaries, brokers, and go-betweens to articulate the global and the conjunctural, thus proposing another genealogy of modernity. The journey that Schaffer invites us to take through a renewed history of metrology-following in the wake of his renewed history of astronomy-means always being ready to take byroads and backstreets in order to better emphasize the plurality of origins and the collection of data through rituals of measurement. Nonetheless, it remains a journey based on what has already happened, a trail leading back from that which imposed itself globally to its many earlier variations, recounted by the voices of the victorious.

Replacing the grand narrative with small histories does not completely succeed in erasing it. First and foremost, astronomy in all its forms remains at the heart of Schaffer's research; he situates himself within its legacy and uses it to broaden his investigation and multiply the episodes of encounters between East and West. But when the tales depict worlds other than those of Europeans, can one really claim to be writing a "history equally shared?" 93 The history of early modern science is precisely not such a history, and showing that this science was produced through a discourse that purged it of its ritual dimensions does not comprehensively allow other types of knowledge to return to center stage in their fullest form, nor account for their exclusion from the spaces of modernity-which suddenly reveals itself to manufacture exclusion. Let me be clear: this is not about reintroducing by a new means something that has already been rejected, nor is it a pretext for returning to the Eurocentrism of the narrative of the scientific revolution. It is possible to attempt, however, to take seriously the localized aspect of the elaboration and articulation of modernity, science, globalization, and capitalism. The first step would imply considering this history as one history among others.

Given the current state of research in the history of science, it is unclear whether other paths exist if "early modern science" is the only object of inquiry. 
The extension of the spaces of investigation, however, could lead to other approaches to "European sciences" as configurations of knowledge that non-European actors relayed to other configurations of knowledge that would have been more familiar to them and against which they might measure the world. In this respect, even if analyzed from a solely European perspective, the early modern period would not be reduced to a single mode of rendering the world intelligible. The work of the historian of science could perhaps accomplish more than simply feeding the historiographical asymmetry from which his or her area of study still suffers. Understood as one regime of spatiality competing with others, the global scale could offer new ways of grasping the variability of modes of understanding the world that coexisted and were occasionally confronted with one another between the fifteenth and the eighteenth century. The scale itself would not constitute a horizon of explanation a priori. And it would make it possible to do away with modernity as a product of the early modern period.

Having reached the end of this discussion, we should be grateful that Schaffer has confronted the issues raised by writing the history (of science and technology) of the early modern period with an elegance worthy of his favorite creators of history: novelists. He reminds us that the practice of proving something is also an exercise in persuasion and, like Swift (who is cited at various points throughout his work), invites us to follow him through laughter. His writings make frequent use of irony as a literary technology in order to identify and valorize the gaps between our implicit expectations and the blindness they can provoke. This is necessary. And when it is a matter of measuring time, the revelation of these gaps is particularly welcome: on the faces of our clocks, the time here is not the same as the time over there, no more than today's time is the same as yesterday's. ${ }^{94}$ One should always remain curious about this elsewhere of other peoples. If we have barely begun to notice the threads that connect us to them, how can we be ready to think about historiographical procedures that will not be exclusively centered on those who made the clocks that mark out our own systems for measuring and writing time?

It is therefore tempting to conclude with a rather optimistic diagnosis. By breaking away from the scientific revolution as a foundational act written in a linear way, new studies of science have in no way undermined the legitimacy or the interest of research on scientific and technological knowledge. They have shattered the notion that has been most influential in forging the paradigm of modernity as it is formulated today, namely the alliance of science and progress. By deconsecrating the subject of science, by historicizing both its composition and the multiplicity of practices from which it results, the work accomplished over the last decades encourages a pluralization of analyses addressing the making of the early modern 
sciences, along with the mythologies that accompanied them. For all who take up the challenge, however, the path that avoids substituting the myth of globalization in progress for that of triumphant modernity is a narrow one.

Antonella Romano

Centre Alexandre Koyré - EHESS 